\title{
THE TRANSFORMATION OF PORT CITIES: LOCAL CULTURE AND THE POST-INDUSTRIAL MARITIME CITY
}

\author{
GÜNTER WARSEWA \\ Institute for Labour and Economy (IAW), University of Bremen, Germany
}

\begin{abstract}
Regardless of size or location, port cities were strongly affected by industrial decline and forced to reinvent themselves. The port city we once knew was coined by a particular identity and culture, but now a new type of maritime city emerges with high-tech production, research institutions, tourism, leisure and other services. So, the port city in western countries underwent serious changes in its historic development path. In this process of transformation, one of the most important challenges was and is to change thinking and mentalities. The more distinctive the port city, the more exclusive and specialised its profile, culture and character - products of a historic legacy of maritime trading, seafaring, shipbuilding and all their related productive and service capacities - the greater the difficulty of responding to these challenges. Nonetheless, the changing patterns of local structures reflect essential elements and expressions of a typical local culture. The following reflections will argue that (1) "local culture" forms a third factor besides the socio-economic structures and the institutional system, which strongly determines the local development; (2) this "local culture" is more or less a common characteristic of port cities all over Europe and in the western industrialised parts of the world, which have their roots in the European history (i.e. in USA or Australia) and (3) even today the typical maritime "local culture" plays an important role for the development of the postmodern port city, in spite of the strong forces of globalisation. Local culture affects the process of transformation by various functions. Hence, the typical development paths of port cities are not just pure adaptations to global dynamics. They are more an expression of a certain cultural autonomy reproducing the individuality and the diversity of port cities as well as their differences to the territorial, inland towns.
\end{abstract}

Keywords: port city, structural change, local culture, globalization, adaptation, path dependency, urban development.

\section{INTRODUCTION: THE END OF THE TRADITIONAL PORT CITY}

Since the 1970s port cities across the western industrialised world were forced to reinvent themselves. During the second half of the 20th century port operations had ceased, the port itself had been relocated and traditional maritime industries had been lost or reduced in many places. Numerous other activities had lost their economic viability, job numbers and tax incomes had decreased dramatically and whole districts had fallen into decline. At the same time port cities were no longer the sole major gateway between the national economy and international markets or the source of economic and marine military power. Likewise, institutional arrangements (e.g. port authorities, harbour police, customs offices, specific associations, facilities for developing skills and training in the marine industries), which had previously contributed to building and underpinning the port cities' specialist niche, had been eroded and made partially redundant. In any case their transformation and modernisation had become essential. The more distinctive the port city, the more specialised its profile and character acquired from a legacy of centuries of maritime trading, seafaring, shipbuilding and related productive and service capacities, the greater the difficulty of responding to structural change. 


\section{THE ROLE OF CULTURE IN LOCAL DEVELOPMENT}

While undergoing these processes, port cities were seized by a feeling of uncertainty about their own identity and a loss of self-confidence. Options for further development were extremely unclear and it was difficult to make decisions for future development. However, the crisis of the 1980s and 1990s exposed a fundamental reality: there is a close linkage between local institutions, local economic and social structures and local culture. These elements mutually support and reinforce one another in a way that leads to the typical specialisation of the port city and produced a highly stable development path in the past [1]. In this regard the development of most port cities over the centuries is based on the coherence of its economic and institutional structures and their particular local ensemble of "culture, informal rules and history" [2].

"Local culture" in this sense represents an ensemble of common practices, attitudes, symbols and the use of language and meanings, which express and collectively reproduce shared expectations, norms and conventions. Hence, local culture covers a wide range of material artefacts as well as collective values and shared basic assumptions, which are reflected in typical daily routines, particular customs or manners [3], [4]. Local culture thus forms a commonly accepted and locally defined framework for the actions of both individual and collective players. Being embedded in this framework means that:

- a sense of affiliation is established and leads to reciprocal trust and reliability,

- cooperation can build on shared orientations and conventions, and

- individual decisions on economically or politically relevant alternatives are generally taken in a collectively accepted framework.

The following reflections will expose those typical characteristics of local culture which are inseparably tied up with the history and tradition of the port city in the industrialised western world, and which, in spite of being embedded in national cultures and systems, can be identified in every port city across Europe. Moreover, the discussion will focus on how and to what extent local culture still contributes to the development and re-invention of the port city today.

\section{LOCAL CULTURE AS A FACTOR OF STABILITY AND DRIVER OF CHANGE}

It can be assumed that all the different cultural codes of the "aristocracy of merchants", dock-workers and shipbuilders, seafarers, port authority officials and administrators, customs bureaucracies or local politicians were generally embedded in a framework of common interests regarding the port cities' autonomous capacity to act and the maintenance of its maritime functions. This common and overarching framework established the foundations for a common identification - both in the local self-image as well as in the view from outside: The residents of the north German Hanseatic cities are still today seen as "Hanseatics" - even if neither they nor anyone else can define a Hanseatic personality [5]; the inhabitants of Liverpool are called "Scousers" after their seafarers dish and "Scouse is everything that constitutes a Liverpudlian soul, in no matter which corner of the world its origins lie. Scouse is the barely understandable dialect, the merciless sarcastic humour or the deliberate refusal of London's dominance - all widely distributed across the motley population of Liverpool" [6].

Within the context of globalised relations local culture is often seen as a folkloric remnant without any influence on current social and economic processes and, moreover, doomed to steadily fade away. But this is only one side of the coin: as a result of increasing competition between regions and cities, the tangible and intangible elements of local culture were rediscovered and put on stage as an indicator of uniqueness in the course of 
regeneration strategies and image campaigns. Additionally, this framework of shared norms, values, attitudes and meanings consolidates itself over times in collective identity and memory. Therefore, it is still viable as an active mechanism for driving and co-ordinating the development of the port city in different ways. Taking into account that the typical structure and functionality of local culture is always closely linked to social, economic and environmental conditions, four typical qualities can be identified, which - in various forms - play an essential role in the thinking and behaviour of relevant actors in port cities. Port cities are:

- specialised systems of functions;

- risk communities;

- hubs of flows;

- centre and periphery.

\subsection{Port cities as specialised systems of functions: persistence despite diversification}

In each port city many artefacts and symbolic motifs related to seafaring and long-distance trade are to be found in the cityscape and in urban structures. As a visual expression of the emergence and consolidation of a maritime-oriented local culture, they are constantly reflecting its specialist functions. In each historic period a typical picture was composed of architectural forms, technical features, traffic infrastructure, etc. which until the present day can still be recognized: "Storehouses were distributed across the entire area of Amsterdam, but for the most part they were concentrated on those artificial islands that were built in the late 16 th and early 17 th century at the quayside. They were (and to a certain degree remain today) a strange world in miniature, a mixture of warehouses, shipyards, timber storageyards, tow-rope lanes and sheds for drying and smoking herring" [7].

Just as the Manuelinian Gothic Style at Lisbon provided a unique symbol of the rise of Portugal as a global seafaring power, many of these cultural expressions of functional specialisation lost their original meaning with contemporary development. Indeed, there are many causes which seem to confirm the hypothesis of a more and more disembedded local culture. The global convergence of living conditions and lifestyles finds its expression in a steadily growing similarity of material and functional elements in all cities as well as in the adaptation of cultural practices. Far distant townscapes and living areas develop a similar appearance, but the worldwide emergence of a global culture also enhances the disintegration of local culture. Affiliation to or identification with, a "global" culture leads to increasing social distinction on the local level and thus to a steady expansion in the distance between the cultural codes of differently "globalised" and "modernised" milieus.

Both of these processes - disembedding and heterogenisation - result in a paradoxical situation: on the one hand, many of those images, symbols or material objects which produce and reproduce the sense and spirit of a particular place are continuously present in the urban form. On the other hand, the same expressions lose their original meaning in the process of disembedding of the local culture; thus, becoming a matter of reinterpretation and new attribution of sense. The typical outlines of sheds and warehouses for example once symbolised the exuberant wealth of manifold goods, but also the hard physical work needed to handle those goods. These days they mainly represent a particular quality of leisure and event associated with the use of all kinds of consumer offers. Nevertheless, all these objects, symbols and signs demonstrate by their very survival and adaptability to new uses a certain durability of local culture - even when it is disentangled from its social and economic base. 
This paradoxical simultaneity of persistence and changeability is a typical characteristic of periods of uncertainty and crisis. In particular, during these processes, critical or provocative interventions are needed to initiate new discourse about potential future perspectives and options for development. In many port cities local artists generate such innovative initiatives. This is what young artists did who set up a viable centre for contemporary art, architecture and urban planning at the former Lenin-Shipyard in Gdansk. Occupying and redefining traditional places, old symbols and their meanings they provoke disputes about traditional meanings and conventional attitudes, which in other social groups or milieus are unquestioned. While, for instance, the history of the Solidarnosc-movement is celebrated in Gdansk by an impressive exhibition entitled "Road to Freedom", the young artists at the Lenin-shipyard put their individual freedom to use in a variety of productions that tackle the sometimes mythical transfiguration of the more recent history of the location [8].

When certain parts of local culture are questioned and identified as inadequate, they may lose their function as guideline and stabiliser of attitudes and practices. But the case of the former Lenin-Shipyard in Gdansk demonstrates the coexistence of provocation on the one hand and an affirmative handling of traditional symbols and meanings on the other. In every port city we find the inevitable maritime museum, historic workshops, maritime heritage trails, open shipyards, maintaining tradition, old working techniques etc. Many of these institutions contribute to a certain reconciliation between modern developments and the considerable number of losers of structural change. The explicit reference to the traditional elements of local culture - for instance in contemporary architecture as in the example of the Euskalduna-Concert Hall and Congress Centre in Bilbao, whose materials and shape are a reminder of the former Euskalduna-shipyard - is not at least an expression of respect and appreciation for services once rendered and may help to reduce the depression caused by deprivation and uncertainty.

Moreover, local culture plays an important role in contributing to processes of place-making and image-building in post-Fordist renewal strategies. Maritime artefacts and ambience help to add a certain character and 'personality' to new forms of consumption, tourism and leisure opportunities. The individuality of the place becomes a unique selling point and is put on show. Thus the port city becomes an 'exhibited city', which is presented as a place, where an 'authentical' local culture can be experienced.

Many examples refer to the fact that the process of place-making as well as of image-building depend on the appropriation of the specific local culture. The most obvious example of the inherent ambivalence is the historic City of Venice, which has very successfully presented itself as a city on show since the decline of its political and economic power. Venice as a city on show means the experience of a rich maritime culture, which sometimes is hidden behind the giant advertisements of global brands. But, by many visitors the mere existence of these symbols of an unspecified global culture might be decoded as proof of the value and significance of the surrounding local culture.

Today, in most of the port cities, bigger or smaller waterfront development projects reflect both the durability of local culture as well as its changes. Projects like Darling Harbour in Sydney, the London or Dublin Docklands, the Port Vell in Barcelona or the Porto Antico in Genoa, the Overseas City in Bremen or the HafenCity in Hamburg are producing a new sense of place. A typical quality of experience and ambience is given to the emerging mix of marinas, office buildings, lofts and high quality housing estates, shopping malls, multiplex-cinemas, food-courts, congress-centres, museums, aquariums only through the use of maritime symbols. Finally, not even Bilbao, where the 
'Guggenheim-effect' is seen as an impulse for a radical change of local development, does without a local maritime museum, which is integrated into the new inner urban development axis.

So, the various elements and expressions of local culture and their appropriation have several functions in urban regeneration processes: they may serve as inspiration and provocative incentive for innovation, as a moderator of social stabilisation, as a potential or resource for place-making and image-building. This means firstly, that local culture reproduces itself or is being reproduced in the process of renewal and secondly, that the diversification of economic structures is to a certain extent bound to the individual local culture.

\subsection{Port cities as risk communities: cooperation, public spirit and maritime consensus}

Historically, seafaring and long-distance trade were always characterised by extraordinary risk for humans and materials, for investment, for the physical existence and social status of the persons involved. The consequences of risk materialising - loss of cargo and ships, depreciation through the volatility of markets or political intervention, illness or even death or social deprivation - were concentrated in port cities as much as the potential for profit. None of these uncertainties were ever completely controllable, but manifold strategies were developed in port cities to provide a rational way of handling the highly speculative character of overseas trade and seafaring. And it is one of the fundamental experiences that strategies to reduce uncertainty and for the rational management of inevitable risk only work collectively, for instance by political coverage of trading privileges, or by distributing risk among a number of different parties.

Obviously, the establishment of the Hanseatic League was such a mechanism for risksharing. Merchants and towns formed an efficient network which over centuries played a powerful political role in Europe. Within and among the towns involved the mechanisms for the regulation and coordination of behaviour were, in addition to hierarchical power and market-oriented competition, characterised by a strong element of cooperation. Simultaneously, mutual relationships among relevant actors permanently changed from cooperation to competition and vice versa. This is why the towns involved never allowed the Hanseatic League to establish itself as a durable or statutory political institution [9].

So, the management of huge economic and social risk led to a culture of cooperation in the interior structures of port cities which was also reflected in solidary forms of joint risksharing. A typical expression of this culture of cooperation is the annual "Schaffermahlzeit" in Bremen, originally devoted to helping ship-owners and merchants care for sailors and their families. Before the ships set sail again after the winter break, more than 300 participants gather for a farewell dinner, for which both the menu and rules have remained unchanged since 1545. During the event the pension register was (and is still today) completed by ship-owners and merchants.

Traditional institutions like the "Schaffermahlzeit" in Bremen - or the "Sposalizio col Mare", which every year celebrates and renews the symbolic marriage of the Venetian Republic with the sea - still play an important role in building a sense of confidence among elites in the port city and in its communications with the outside world. These institutions symbolise the former ruling 'maritime consensus' and gradually reproduce the sense for cooperation and the maritime consensus in contemporary form; i.e. of civil engagement, sponsorship and patronage.

The traditional maritime consensus works as a mechanism for establishing and reproducing a certain commonality of interests. This becomes even more evident with the 
decline of industry and the intense efforts that have taken place to rebuild and diversify productive capacities. During this period, nearly all port cities began to witness deep conflict, which reflected their uncertainty about future options. Typical examples of this were the hard confrontations that took place in many port cities between those in favour of maintaining existing port functions (the 'working port') and those advocating large renewal projects aimed at establishing a new "living port". The increasingly complicated relationship between port and city was and remains for a number of years one of the major issues debated across the maritime world [10], [11]. 'Working port' and 'living port' not only represent different functional, architectural and spatial concepts, they also stand for different socio-economic coalitions of interests and urban regimes struggling for dominance in local development [12]. Today these conflicts have been resolved nearly everywhere and the protagonists of the emerging new mix of post-industrial functions, such as real estate business, tourist and leisure industry, have evolved into the renewed maritime consensus.

A particularly telling example of cooperative risk management is the radical change of direction undertaken very successfully by the City of Bilbao. The delivery of the Guggenheim Museum as a starting point for regeneration turned out to be a highly risky and speculative investment in the expansion of global arts, culture and tourism markets. It could only be achieved by collaboration in a network of highly confident local players, external professional experts from the global arts market and city-planners and architects with a major international reputation [13]. While the Guggenheim Foundation wished through its involvement in Bilbao to accelerate its transformation from a traditional cultural foundation to a global player in arts markets, representatives of the City of Bilbao described the risky change of direction like a merchant as "buying a new identity". So, the entrance of Bilbao into the global casino of arts and cultural markets could just as well have been headed up by the traditional slogan of the Hanseatic merchants of Bremen: "Buten un Binnen - Wagen un Winnen" (engl.: Outside and Inside - Venture and Win).

There are many evidences for the fact that taking recourse to traditional elements of local culture eases the process of overcoming internal controversies and helps to mobilise the energy needed to respond to huge challenges. Therefore, in periods of high uncertainty and reduced capacity to act, local culture proves to be an important resource for coping with the crisis. Even where the societal consensus, previously completely focused on the functioning of the port, now integrates new functions and their social representatives, it has retained its character of steering mechanism. As such, the renewed maritime consensus contributes to the capacity of the port city to control its actions and to preserve a maritime character.

\subsection{Port cities as hubs of flows: foreignness as normality}

As long as sea transport remained the most efficient way to overcome great distances, its function as the hub of different flows was a major characteristic of the port city. This was the place where all kinds of flows - goods, capital, information, people, ideas and cultural influences - met together and specific skills and competences were developed as a result of dealing with these flows. Functions such as the appraisal and quality assessment of exotic goods, the specialist expertise of port-doctors or quarantine offices, or a variety of more trivial offers in the port near red-light districts, all dealt with diversity as a normal part of everyday business. The capacity for cultural exchange and profitable dealings with foreigners were vital ingredients to securing successful seafaring and long-distance trade as well as the successful functioning of the port as a hub of flows. 
In foreign relations this was reflected in the creation of a certain 'exile-ability', i.e. the qualification for 'leaving' and 'functioning' home- and interest-related, even when far from home and working for long periods of time in unfamiliar conditions [14]. A typical example of this practice was the establishment of Hanseatic Offices in medieval times as the home-like base of merchants' communities in their principal destinations. Another common practice among merchants was to send their sons for apprenticeship to the offices of other merchants in foreign countries. Combined with collective strategies for risk management, these arrangements also contributed to creating cosmopolitan attitudes and at the same time intense binding to the place of origin and its functionality.

Dealing with foreignness also was and is an everyday norm inside the port cities. Contact with diverse groups of temporary city users - pilgrims, soldiers, immigrants and emigrants, business partners, sailors, etc. - shaped the functions of the town and its social life. A considerable proportion of the resident population itself was 'at home' only on a temporary basis and lived with the steady interchange of departing and arriving. It can be assumed that the experience of 'strangeness' as normal part of everyday life and a pragmatic understanding of diversity was the fundamental basis of business and an important source of income. A report on Amsterdam dated around 1700 provides an example of this kind of pragmatism: "Besides other malpractices at least 50 music houses are tolerated in the city of Amsterdam where slovenly persons of either sex meet and commit their turpitudes. There also is a place, ... a tolerated bourse or a public meetinghouse for whores and heels, where they meet and initiate their business. As an exculpation for the toleration of these sinful meetings I have heard that, when the East India Fleet comes home, the sailors are so crazy about women, that they would rape the women and daughters of the citizens, if they had not such houses at their disposal" (Carr, 1701, cited in [7]).

Meanwhile, port cities have lost the exclusiveness of their function as universal hubs and this means that in part they have also lost the economic basis for pragmatism in dealing with diversity and foreignness. Those who in former times had been pilgrims, merchants, immigrants, emigrants, soldiers or seafarers in port cities, are today festival- and culturegoers, commuters, migrants, business-people, students, Ryan Air customers, football fans, congress-attenders and science nomads in every town. And, as a result, inland cities like Brussels, Paris or Warsaw no longer lag behind port cities like Antwerp, Marseilles or Gdansk in the heterogeneity and dynamics of residents and user groups.

But, in the inland places differences and diversity are still not yet, as they are in port cities, perceivable as part of a background of common and shared experiences. The local culture of the port city has traditionally been a 'globalised' culture for centuries and it includes a widespread familiarity with the change of roles and perspectives. Therefore, it is a typical feature of port cities to facilitate the integration of immigrants and foreigners and to enable them to contribute to the creation of a common culture. The more effective opportunity for identification and integration in the port city might be the reason why the notorious city of Marseilles was spared by the youth riots of 2005 when cars burned in the suburbs of Strasbourg, Paris and Lyon. There is a suspicion that, despite social deficits, the traditions of the port city still cause a stronger attachment to the town than elsewhere - even among those groups of youngsters with few opportunities. "Marseilles does no better than other towns with deprived workers' residential areas. But I feel a very strong identity and a mixed culture. What is most important is undoubtedly a certain sense of belonging" [15], [16].

With regard to the development of the port city, it becomes evident that cosmopolitan attitudes, social and cultural diversity and a pragmatic and mainly economically motivated 
form of tolerance are definitely compatible with strong ties to the place of residence as well as with a sense of public spirit and cooperation. It seems as though port cities learnt very quickly to make use of the particular combination of diversity and strong self-identification. And this proved to be an important prerequisite for successful economic development in response to the depression of the $1980 \mathrm{~s} / 90$ s and to the newly developing global culture:

Liverpool succeeded in demonstrating its outstanding role for the development of pop music and becoming an internationally recognized trademark when it was European Capital of Culture in 2008. This could only be accomplished on the back of a specific local culture. Barcelona, Bilbao or Genoa present themselves as contemporary centres for global culture-, congress- and city tourism; in Hamburg, the notorious red-light district of St. Pauli has developed into a well-known location for entertainment and cultural attractions for every social milieu.

Indeed, since the 1980s, almost all European port cities have tried to enhance their attractiveness to new target groups and transient visitors by reanimating experiences, practices and traditions which are embedded in the local culture. Even if the specific form of expressions appears in many cases as a nostalgic symbol of a distant past, often replaced by modern forms of cultural activity, port cities succeed in making use of their traditional ability to cope with diversity and with transient visitors. In such cases local culture serves as a resource for new or modernized services and economically successful regeneration [17].

\subsection{Port cities as centre and periphery: autonomy and self-confidence}

Another fundamental element of the port city's local culture was the existential significance of the sea-port in relation to the national state. The sea-port's function as the most important gateway between the national market and the outside world was assured by coordinating and combining a variety of competences, skills and capacities. Throughout history, the primary purpose and reason for existence of the port city was always to deliver, maintain and guarantee accessibility. All of the competences and capacities required for this - highly differentiated functional systems like construction in water and hydraulic engineering, maintaining the safety and security of shipping, ship-building, the careful handling of various kinds of goods and transport technologies right up to the sovereign regulation of tax and customs affairs or the resolution of the complex legal and contractual problems of international sea trade - had been assembled in the port city. Only in such places was it possible to organise the fluent interplay of all these functions and responsibilities.

The particular function of the port city as a 'centre of competence' for the smooth operation of the port was and is an essential element of the identity of the port city. This allowed many port cities to insist successfully on relative autonomy and maintain their right to self-regulate internal and even foreign affairs. As long as the interplay of local culture, economy and institutional structures ensured material prosperity and social welfare, there was a good reason for self-reliance and self-confidence, which emerged in many port cities as an all-encompassing characteristic of the place.

Most obvious expressions of this particular self-confidence are those titles given to the formerly independent Mediterranean town republics of Venice ("La Serenissima", abbreviated from the official state name "La Serenissima Repubblica di San Marco"; The Most Noble Republic of St. Marcus) and Genoa ("La Superba"; The Splendid) which are still in use today. And it is an expression of a similar attitude that the formal titles of both the German town republics - the "Free Hanseatic City of Bremen" and the "Free and 
Hanseatic City of Hamburg" - are a reminder of their continuing special status in the national context. An analogous status was claimed by the wealthy Hanseatic City of Gdansk over long periods in its history: After its successful rebellion against the Teutonic Order in the 15th century Gdansk was placed under the protection of the Polish crown - but only to procure for itself multiple privileges and far-reaching political independence compared with other Polish towns.

Since the rise of the nation-state, in the large territorial countries of Europe, port cities have been and still remain both centre and periphery at the same time. While they perform a central function as hub of different flows, they represent the specialist edge in the framework of the national state, struggling hard to hold its ground against the predominant claims of the nation-state, principally embodied in 'the capital'. Therefore port cities, such as Antwerp, Barcelona, Gdansk, Hamburg, Liverpool, Marseilles are described as 'second city' whose particular 'spirit loci' emerges as a result of its quality as national periphery and counter-pole to the capital [18].

Even today we can find numerous pieces of evidence for the cultural particularity of the Second City and for its antagonistic relationship to the national framework: the Athletic Bilbao sports club, for example, employs a unique counter-model to usual practice in the extremely globalised Spanish soccer league by appointing native Basque players exclusively. And an extraordinary self-consciousness of place is further indicated by the fact, that Bilbao set itself up as 'second city' when it declared its intention to "challenge the country" [13] with its renewal strategy.

Acting in self-confident independence did not only correspond to the attitudes of local elites, it is also led back to the specific and class-encompassing quality of the place. The free 'spirit of an old, and for a long time independent and self-reliant Hanseatic town' [19] is seen as a reason for the fact, that the Polish Solidarnosc-Movement had her origins in Gdansk only: "Here these movements of the Solidarnosc have their roots - not in Szezcin, Wroclaw or Warsaw. There is a spirit of liberty in Gdansk which expresses itself in a traditional deep distrust to those who rule and this spirit of liberty has been alive in Gdansk for many centuries" [19].

Since the 1980s, many port cities have consistently sought to host special events, such as the Olympics, world exhibitions or applied for European Capital of Culture, although port cities had previously been rather remote from such events. But recently they have understood that the expected benefits of image- and branding campaigns were primarily an opportunity to mobilise new resources for an autonomous strategy of modernization and to enhance their own capacity to act. A particularly clear-cut example of this procedure is the development of Genoa. The 'Genoa model' symbolises the strategic grouping of regional, national and international resources on sequential occasions (Football World Cup 1990, Columbus Year 1992, G8-Summit in 2001, European Culture Capital 2004). Just as in the case of port-business the combination of local management and national or international significance and attractiveness allows the port city to use such events to carry out selfdefined urban development strategies, even in opposition to outside authorities [20].

As long as economic success and outstanding national significance guaranteed a certain degree of relative independence the ambivalent status as a 'Second City' was a key element of the local culture of port cities. And, although the political and economic basis of this mechanism eroded with the decline of port functions, it survived as typical orientation for decisions and strategies. The "republican spirit" of the port city is still viable in its reinvention and coping strategies are aimed at maintaining this key element of local culture in a modernised form, which at the same time can be successfully deployed as a resource for substantial regeneration. 


\section{CONCLUSION: RENEWAL AS EXPRESSION OF INDIVIDUALITY}

Through the generalisation of globalisation trends and an irreversible separation of flows, the comparative advantage of the specialist port city was largely lost. Instead of continuing their traditional development path of specialization, all of the port cities in the western world now seek to carry out a future-oriented diversification of their economic and institutional structures. But, despite every effort to diversify, the maritime character of the port city not only survives, it is actually essential, reinforced and manifested in many ways. Port cities are renewing themselves in some cases even as port cities without a port because the port was removed physically from the inner urban structures. The rediscovery, restoration, redefinition and re-exploitation of both material and symbolic forms and expressions of local culture and their contribution to the 'aestheticisation' of urban structures, to place-making and image-building largely reflects those collective norms and orientations, which formerly emerged from the specific tensions of risk and safety, affiliation and a sense of 'the other' as well as of centre and periphery.

Hence, local culture is anything else than a "soft factor". It proves to be the most sustainable dimension of local or regional development, both carrying forward pathdependency during the process of reinvention of the port city and, limiting deviation from the traditional path. Not at least, the extent to which path deviation or even a change of direction gains acceptance is primarily determined by the degree to which local culture and identity themselves dissolve into different 'globalised' parts and subcultures. So, in no way is local culture and identity diluted or removed by globalisation processes. Even when the economy and institutions lose their functions, local culture takes over as a steering mechanism and a reservoir for important resources that make a considerable contribution to defining the direction of local development.

So, the renewal of the port city does not in any way follow a purely adaptive logic, which makes the impact of global dynamics the crucial determining factor in local development. Instead, there are many examples which demonstrate that the local culture of port cities is an expression of a certain autonomy and individuality, which, in the process of renewal and reinvention, also reproduces typical differences with inland town as well as the typical commonalities of port cities.

\section{REFERENCES}

[1] Lee, R., The Socio-economic and demographic characteristics of port cities: A typology for comparative analysis? Urban History, 25(02), pp. 147-172, 1998.

[2] Hall, P.A. \& Soskice, D., Varieties of Capitalism: The Institutional Foundations of Comparative Advantage, Oxford, pp. 12-13, 2001.

[3] Kluckhohn, F.R. \& Strodtbeck, F.L., Variations of Value Orientations, Evanston, 1961.

[4] Schein, E., Organizational Culture and Leadership, 2nd ed., San Francisco, 1992.

[5] Wegner, M., Hanseaten, München, 2008.

[6] Welt N24, Eine Stadt im Ohr der ganzen Welt, 2008, http://www.welt.de/reise/article1516954/Eine_Stadt im_Ohr_der_ganzen_Welt.html. Accessed on: 6 Jan. 2017.

[7] Girouard, M., Die Stadt, Frankfurt/New York, pp. 158-160, 1987.

[8] Partum, B., Dockwatchers. About the exhibition "Dockwatchers", presented by the Instiytut Sztuki Wyspa at Gdansk 2005, http://www.springerin.at/dyn/heft text.php? textid=1681\&lang=de. Accessed on: 6 Jan. 2017.

[9] Picchierri, A., Die Hanse - Staat der Städte, Opladen, 2000. 
[10] Alix, Y., Delsalle, B. \& Comtois, C. (eds), Port-City Governance, Fondation Sefacil: Le Havre, 2014.

[11] Code of Practice on Societal Integration of Ports, ESPO (European Sea Ports Organisation), 2010, http://www.espo.be/media/espopublications/ESPOCodeof PracticeonSocietalIntegrationofPorts2010.pdf. Accessed on: 6 Jan. 2017.

[12] Stone, C., Urban regimes and the capacity to govern: a political economy approach. Journal of Urban Affairs, 15, pp. 1-28, 1993.

[13] Zulaika, J., "Miracle in Bilbao": Basques in the Casino of Globalism. Basque Cultural Studies, eds. W. Douglass, C. Urza, L. White \& J. Zulaika, pp. 262-274, Center for Basque Studies University of Nevada: Reno, 2000.

[14] Sloterdijk, P., Philosophische Aspekte der Globalisierung. Deutsche Fragen. Wohin führt der globale Wettbewerb? ed. Bundesverband deutscher Banken, pp. 50-71, 2000, https://bankenverband.de/media/publikationen/wohin-fuhrt-der.pdf. Accessed on: 6 Jan. 2017.

[15] Le Monde, 100 raisons d'être optimiste, 14 Jan. 2006.

[16] Parodi, P., Citoyenneté et intégration: Marseille, modèle d'intégration? Cultures \& Conflits, Saint Quen, 2002.

[17] Umbach, M., A Tale of second cities. autonomy, culture, and the law in Hamburg and Barcelona in the late nineteenth century. The American Historical Review, 110(3), pp. 659-692, 2005.

[18] Jones, A.L., Regenerating urban waterfronts - creating better futures - from commercial and leisure market places to cultural quarters and innovation districts. Planning Practice \& Research, 2016, http://dx.doi.org/10.1080/02697459. $\underline{2016.1222146}$

[19] Röhl, B., "Es gibt Ressentiments gegenüber Deutschland". Interview with the Mayor of Gdansk, P. Adamowicz, Cicero Nov. 2004.

[20] Hodos, J., Second Cities. Globalization and Local Politics in Manchester and Philadelphia, Philadelphia, 2011. 